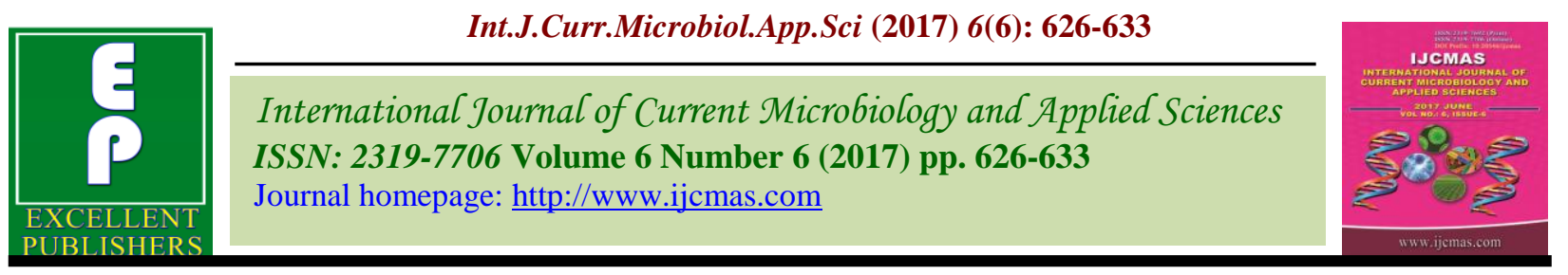

Original Research Article

https://doi.org/10.20546/ijcmas.2017.606.074

\title{
Efficacy of Newly Developed Microbial Consortium for Composting of Rural and Urban Wastes
}

\author{
B.C. Game*, C.D. Deokar and P.E. More \\ Mahatma Phule Krishi Vidyapeeth, Rahuri, Ahmednagar, Maharashtra, India \\ *Corresponding author
}

\begin{abstract}
A B S T R A C T
The newly developed cellulolytic microbial consortium was evaluated for its composting efficiency on rural and urban waste in open pit method. During composting highest

Keywords

Composting,

Microbial

consortium,

Rural waste,

Urban waste.

Article Info

Accepted:

04 May 2017

Available Online:

10 June 2017 temperature was recorded in second week in both the rural and urban waste compost pits. The temperature declined gradually thereafter in all the treatments upto 11th week and remained almost stable thereafter. The bacterial and fungal population in composting pits increased gradually and highest population was recorded in initial phase of composting i.e. between 60 to 90 days of composting in test consortium and commercial consortium treated pits, while in uninoculated control pits it took 90 to 120 days for reaching to its maximum. Thereafter a gradual decrease in bacterial and fungal population and increase in actinomycetes population was recorded. The population of actinomycetes was found at peak between 120 and 150 days of composting period. Test consortium reduced the composting period of rural waste by $22.68 \%$ while that of urban waste by $18.39 \%$ over uninoculated control. The treatment with test consortium on both wastes recorded numerically higher mineral content over commercial consortium and uninoculated control. Results indicated that the use of test consortium reduced the overall time required for composting besides producing the nutrient enriched compost product.
\end{abstract}

\section{Introduction}

Composting of organic wastes is a biooxidative process involving the mineralisation and partial humification of the organic matter, leading to a stabilised final product, free of phytotoxicity and pathogens and with certain humic properties (Zucconi and de Bertoldi, 1987). It serves as a mean of environmentally acceptable waste disposal on the one hand and produces organic fertilizers on the other. Composting is not only a waste treatment technique but also a recycling method as the end product can be used in agriculture as fertilizer. As a consequence of increasing fertilizer costs, fluctuating product prices and decreasing soil productivity, the farmers are shifting to the use of organic material as nutrient source. But the availability of organic matter is also factor to put organics in use. The utilization of biodegradable organic fraction of urban wastes, cattle waste and crop residues as a source of plant nutrient can solve the farmer's problem.

The active component mediating the biodegradation and conversion processes during composting is the resident microbial community. Therefore, optimization of compost quality is directly linked to the 
composition and succession of microbial communities in the composting process (Taiwo and Oso, 2004). There is practically no substance existing in nature that is not used by one microorganism or another (Iranzo et al., 2001). It is therefore necessary to identify the microorganisms present in the different processes, as several different species of microbes are usually involved. These microorganisms are also important to maintain nutrient flows from one system to another and to minimize ecological imbalance (Novinsak et al., 2008).

The decomposition process is carried out by various microorganisms including bacteria, fungi and actinomycetes. Different communities of microorganisms predominate during the various composting phases. Initial decomposition is carried by mesophilic microorganisms, which rapidly biodegrade the soluble and easily degradable compounds. As temperature increases on oxidation of carbon compounds, thermophiles take over. Temperature in a compost pile typically follows a pattern of rapid increase to $49^{\circ} \mathrm{C}$ to $60^{\circ} \mathrm{C}$ within 24 to 72 hours of pile formation and is maintained for several weeks. This is the active phase of composting, in which easily degradable compounds and oxygen are consumed, pathogens viz., Escherichia coli, Staphylococcus aureus, Bacillus subtilis, Clostridium botulinum and weed seeds are killed, and phytotoxins are eliminated. As the active composting phase subsides, temperature gradually declines to around $38^{\circ} \mathrm{C}$ and mesophilic microorganisms once again take over the other types of microorganisms and the curing phase begins (Fourti et al., 2008). Although, the microbial community naturally present in the wastes usually carries out the process satisfactorily, the inoculation of wastes with microorganisms that each of them produces one of the several polymer degrading extracellular enzymes at high level is a strategy that could potentially enhance the way the process takes place or the properties of the final product.

In the present study, microorganisms isolated from naturally decomposing wastes were evaluated in-vitro for cellulolytic activity. The consortium of efficient cellulolytic microorganisms was developed and experiment was conducted to see its efficacy on decomposition of organic wastes.

\section{Materials and Methods}

Initially cellulolytic microorganisms were isolated from naturally decomposing organic matter collected from different locations. These isolates were studied for cellulolytic activity and compatibility with each other. The highest cellulase producing microorganisms viz., bacterial isolate B-28 (Bacillus sp), fungal isolate F-13 (Aspergillus terreus) and actinomycetes isolate A-40 (Streptomyces sp.) were incorporated in the consortium. The developed consortium was tested with rural and urban waste for its decomposing ability. Six pits of $1 \mathrm{mt}$ X $1 \mathrm{mt}$ with $1 \mathrm{mt}$ depth were used for the nonreplicated experiment. Three pits were used for composting of rural waste and remaining three for urban waste. Rural waste was collected from the nearby villages and urban waste from Rahuri town. The rural waste comprised of Farm waste, animal fodder waste, animal litter along with dung, while urban waste constituted of vegetable waste, roadside waste, kitchen waste, papers etc. Polythene bags, stones, glass etc. material were separated from the waste before pit filling. Remaining waste was filled in the respective pits.

First pit from both the sets was inoculated with the test consortium, second with commercial consortium (MPKV's decomposing culture) @ $1 \mathrm{gm} / \mathrm{kg}$ of substrate. The third pit in both the sets served as uninoculated control. The pits were watered 
frequently so as to maintain $60-65 \%$ moisture level. Turnings were given at 15, 30, 60, 90 and 120th day of inoculation. Temperature in the core of pit was measured by hand thermometer weekly at fix time. For initial and final $\mathrm{pH}$, samples were taken in $100 \mathrm{ml}$ beaker and diluted 1:10 (1 part sample in 10 parts of distilled water) and placed on shaker for $1 \mathrm{hr}$. The samples were centrifuged at $4000 \mathrm{rpm}$ for $30 \mathrm{~min}$. and filtered through Whatman No.1 filter paper. $\mathrm{pH}$ of the suspension was measured potentiometrically using a combined glass electrode. Organic carbon content of substrates was determined by ignition method (Bremner, 1970). Total nitrogen content of the substrates was determined by modified Kjeldhals method (Piper, 1966). Total phosphorus content was estimated by following the procedure given by Jackson (1973). Total potassium content in an aliquot of tri acid mixture with suitable dilution was estimated using flame photometer (Jackson, 1973). Maturity of compost was recorded on the basis of preestablished maturity and stability parameters of compost (Ranalli et al., 2001; Goyal et al., 2005 and Raj and Antil, 2011).

\section{Results and Discussion}

\section{Changes in temperature during composting}

Changes in temperature at various stages of decomposition in different treatments are shown in table 1 . The temperature in all the compost pits reached maximum (60.2 to $63.4^{\circ} \mathrm{C}$ ) within a week. In both rural and urban waste pits the highest temperature was recorded on inoculation with test consortium which denotes highest microbial activity, followed by MPKV consortium and uninoculated control. The temperature declined gradually thereafter in all the treatments upto 11th week and remained almost stable thereafter upto 20th week of composting.
Taiwo and Oso (2004) reported that in composting experiment a peak of about $70^{\circ} \mathrm{C}$ was attained in the first week of composting. Goyal et al., (2005), Gazi et al., (2007) and Himanen and Hanninen (2011) recorded similar trend of initial increase in temperature and gradual decrease during later stages in composting experiment.

\section{Microbial population during composting}

The changes in microbial population were recorded periodically and are presented in table 2. Bacterial population in the compost pits treated with test consortium was maximum at 60 days of composting, while in commercial consortium treated pits and uninoculated control it took 90 days to reach at maximum. Thereafter the bacterial population gradually decreased in all the pits. The fungal population increased with time and reached maximum at 90 days of composting in both the consortium treated pits, while it took 120 days to reach maximum in the untreated pits. While the population of actinomycetes attained its highest in composting pits at 120 to 150 days of composting. Among the microorganisms, bacteria were active in the initial stages of composting, while with gradual decrease in temperature the fungi take over the process. Actinomycetes were active in the later stages of composting and were generally involved in the compost stability. Similar trends on microbial population during different stages of composting process have been reported by Hassen et al., (2001), Haritha Devi et al., (2009), Goyal et al., (2005) and Gazi et al., 2007.

\section{Days required for compost maturity}

In the present experiment, decomposition of rural waste treated with test consortium completed in least time i.e. 92 days, which reduced the composting time over control by $22.68 \%$ and over commercial consortium by $10.67 \%$. 


\section{Int.J.Curr.Microbiol.App.Sci (2017) 6(6): 626-633}

Table.1 Changes in temperature during composting of rural and urban waste

\begin{tabular}{|c|c|c|c|c|c|c|c|c|c|c|c|c|c|c|c|c|c|c|c|c|c|c|}
\hline \multirow{2}{*}{$\begin{array}{l}\text { Sr. } \\
\text { No. }\end{array}$} & \multirow{2}{*}{$\begin{array}{l}\text { Subst- } \\
\text { rate }\end{array}$} & \multirow[t]{2}{*}{ Consortia } & \multicolumn{20}{|c|}{ Weekly Average temperature $\left({ }^{\circ} \mathrm{C}\right)$} \\
\hline & & & 1 & 2 & 3 & 4 & 5 & 6 & 7 & 8 & 9 & 10 & 11 & 12 & 13 & 14 & 15 & 16 & 17 & 18 & 19 & 20 \\
\hline \multirow[t]{3}{*}{1} & \multirow[t]{3}{*}{$\begin{array}{l}\text { Rural } \\
\text { waste }\end{array}$} & $\begin{array}{l}\text { Test } \\
\text { consortium }\end{array}$ & 47.1 & 63.4 & 57.2 & 50.6 & 46.5 & 44.1 & 40.5 & 38.4 & 37.8 & 31.5 & 30.6 & 31.1 & 29.8 & 30.0 & 30.5 & 30.1 & 29.2 & 28.5 & 29.0 & 28.4 \\
\hline & & $\begin{array}{l}\text { Commercial } \\
\text { Consortium }\end{array}$ & 46.3 & 61.5 & 58.2 & 52.1 & 47.6 & 45.2 & 42.9 & 39.5 & 36.5 & 31.0 & 30.5 & 30.2 & 30.0 & 29.7 & 30.9 & 30.3 & 29.5 & 28.1 & 29.1 & 28.5 \\
\hline & & $\begin{array}{l}\text { Un- } \\
\text { inoculated } \\
\text { Control }\end{array}$ & 42.9 & 60.2 & 59.5 & 53.0 & 48.2 & 45.6 & 42.1 & 39.0 & 36.8 & 31.2 & 30.7 & 31.2 & 30.1 & 29.8 & 29.9 & 30.4 & 29.6 & 28.4 & 29.2 & 28.4 \\
\hline \multirow[t]{3}{*}{2} & \multirow[t]{3}{*}{$\begin{array}{l}\text { Urban } \\
\text { waste }\end{array}$} & $\begin{array}{l}\text { Test } \\
\text { consortium }\end{array}$ & 49.0 & 62.5 & 58.7 & 51.6 & 42.5 & 40.8 & 40.2 & 39.1 & 36.6 & 30.8 & 31.4 & 29.7 & 30.4 & 29.2 & 30.0 & 29.8 & 29.5 & 28.4 & 29.2 & 28.3 \\
\hline & & $\begin{array}{l}\text { Commercial } \\
\text { Consortium }\end{array}$ & 47.8 & 61.4 & 58.9 & 52.4 & 42.6 & 41.2 & 41.0 & 39.4 & 36.5 & 30.9 & 30.7 & 30.1 & 30.4 & 29.4 & 30.2 & 29.7 & 29.4 & 28.2 & 29.3 & 28.5 \\
\hline & & $\begin{array}{l}\text { Un- } \\
\text { inoculated } \\
\text { Control }\end{array}$ & 45.7 & 60.7 & 59.1 & 52.7 & 42.5 & 40.9 & 40.5 & 39.3 & 36.7 & 31.0 & 30.7 & 30.2 & 30.3 & 29.5 & 30.3 & 29.7 & 29.5 & 28.5 & 29.4 & 28.4 \\
\hline
\end{tabular}

Initial C:N ratio: Rural waste- 59.43, urban waste- 36.67 Initial $\mathrm{pH}$ : Rural waste- 6.70, urban waste- 6.23 
Table.2 Population of microorganisms during composting of rural and urban waste

\begin{tabular}{|c|c|c|c|c|c|c|c|c|c|c|c|c|c|c|c|c|c|c|c|c|c|c|}
\hline \multirow[b]{2}{*}{$\begin{array}{l}\text { Sr. } \\
\text { No. }\end{array}$} & \multirow[b]{2}{*}{ Substrate } & \multicolumn{7}{|c|}{ Test Consortium } & \multicolumn{7}{|c|}{ MPKV Consortium } & \multicolumn{7}{|c|}{ Uninoculated Control } \\
\hline & & $\begin{array}{l}\text { Initi } \\
\text { al }\end{array}$ & $\begin{array}{l}30 \\
\text { days }\end{array}$ & $\begin{array}{l}60 \\
\text { days }\end{array}$ & $\begin{array}{l}90 \\
\text { days }\end{array}$ & $\begin{array}{l}120 \\
\text { days }\end{array}$ & $\begin{array}{l}150 \\
\text { days }\end{array}$ & $\begin{array}{l}180 \\
\text { days }\end{array}$ & $\begin{array}{l}\text { Initi } \\
\text { al }\end{array}$ & $\begin{array}{l}30 \\
\text { days }\end{array}$ & $\begin{array}{l}60 \\
\text { days }\end{array}$ & $\begin{array}{l}90 \\
\text { days }\end{array}$ & $\begin{array}{l}120 \\
\text { days }\end{array}$ & $\begin{array}{l}150 \\
\text { days }\end{array}$ & $\begin{array}{l}180 \\
\text { days }\end{array}$ & $\begin{array}{l}\text { Initi } \\
\text { al }\end{array}$ & $\begin{array}{l}30 \\
\text { days }\end{array}$ & $\begin{array}{l}60 \\
\text { days }\end{array}$ & $\begin{array}{l}90 \\
\text { days }\end{array}$ & $\begin{array}{l}120 \\
\text { days }\end{array}$ & $\begin{array}{l}150 \\
\text { days }\end{array}$ & $\begin{array}{l}180 \\
\text { days }\end{array}$ \\
\hline \multicolumn{23}{|c|}{ A) Bacteria (x10 ${ }^{7} \mathrm{cfu} / \mathrm{g}$ of dry matter) } \\
\hline 1 & \begin{tabular}{|l} 
Rural \\
waste \\
\end{tabular} & 9.6 & 27.3 & 54.0 & 47.3 & 33.0 & 28.0 & 27.3 & 4.3 & 16.3 & 44.6 & 43.6 & 36.0 & 29.0 & 28.0 & 2.3 & 15.6 & 43.0 & 46.6 & 32.3 & 28.3 & 25.0 \\
\hline 2 & \begin{tabular}{|l|} 
Urban \\
waste
\end{tabular} & 11.3 & 36.0 & 66.3 & 51.6 & 39.6 & 31.3 & 29.0 & 10.0 & 23.6 & 53.0 & 56.3 & 42.3 & 33.3 & 27.6 & 6.0 & 20.0 & 50.3 & 53.6 & 36.0 & 29.0 & 26.3 \\
\hline \multicolumn{23}{|c|}{ B) Fungi (x10 ${ }^{4} \mathrm{cfu} / \mathrm{g}$ of dry matter) } \\
\hline 1 & $\begin{array}{l}\text { Rural } \\
\text { waste } \\
\end{array}$ & 26.3 & 31.3 & 43.3 & 51.3 & 49.3 & 36.0 & 31.0 & 27.6 & 33.3 & 40.0 & 53.0 & 52.3 & 40.2 & 33.4 & 16.0 & 20.3 & 36.3 & 48.6 & 51.3 & 44.0 & 32.3 \\
\hline 2 & \begin{tabular}{|l|} 
Urban \\
waste
\end{tabular} & 23.0 & 29.3 & 44.6 & 53.3 & 51.3 & 39.6 & 33.0 & 25.3 & 28.6 & 37.3 & 52.3 & 50.0 & 39.6 & 36.6 & 14.3 & 19.0 & 33.3 & 49.0 & 58.0 & 43.6 & 33.6 \\
\hline \multicolumn{23}{|c|}{ C) Actinomycetes $\left(\times 10^{5} \mathrm{cfu} / \mathrm{g}\right.$ of dry matter) } \\
\hline 1 & $\begin{array}{l}\text { Rural } \\
\text { waste } \\
\end{array}$ & 17.6 & 21.3 & 24.0 & 36.3 & 53.3 & 50.6 & 46.0 & 4.3 & 8.6 & 16.6 & 24.3 & 41.0 & 48.3 & 43.3 & 3.6 & 14.3 & 20.6 & 39.6 & 49.0 & 43.3 & 40.0 \\
\hline 2 & $\begin{array}{l}\text { Urban } \\
\text { waste }\end{array}$ & 15.3 & 20.0 & 24.3 & 36.0 & 64.6 & 56.3 & 49.0 & 3.6 & 6.0 & 13.3 & 26.6 & 47.0 & 33.3 & 46.3 & 3.3 & 11.0 & 23.3 & 41.6 & 54.6 & 50.3 & 44.3 \\
\hline
\end{tabular}

(Initial population: 24 hrs. after inoculation)

Table.3 Average number of days required for compost maturity, its final C:N ratio, $\mathrm{pH}$ and mineral components

\begin{tabular}{|c|c|c|c|c|c|c|c|}
\hline Substrate & Consortia & $\begin{array}{l}\text { Days for } \\
\text { maturity }\end{array}$ & $\mathrm{C}: \mathrm{N}$ ratio & pH & $\begin{array}{l}\text { Total nitrogen } \\
(\%)\end{array}$ & Total phosphorus (\%) & Total potassium $(\%)$ \\
\hline \multirow{3}{*}{ Rural waste } & Test Consortium & 92 & 14.47 & 7.07 & 0.59 & 0.46 & 1.09 \\
\hline & MPKV Consortium & 103 & 15.53 & 7.11 & 0.57 & 0.42 & 1.07 \\
\hline & Uninoculated control & 119 & 16.67 & 7.14 & 0.57 & 0.44 & 1.06 \\
\hline \multirow{3}{*}{ Urban waste } & Test Consortium & 71 & 13.69 & 6.94 & 1.26 & 0.97 & 0.67 \\
\hline & MPKV Consortium & 79 & 14.01 & 6.90 & 1.13 & 0.89 & 0.64 \\
\hline & Uninoculated control & 87 & 14.58 & 6.86 & 1.11 & 0.88 & 0.63 \\
\hline
\end{tabular}


Same trend was recorded in the urban waste composting. The urban waste inoculated with test consortium decomposed in 71 days. The per cent decrease in time by test consortium treated urban waste over control (Commercial Consortium) was $18.39 \%$, while over uninoculated control was $10.12 \%$.

Thus, it is possible to increase the decomposition rate of organic matter, whatever the characteristics of the waste may be Gaur (1982) reported that due to inoculation of mesophilic fungi, the period of composting was reduced by one month.

Reduction in composting period due to inoculation of cellulolytic microorganisms has also been reported by Raut et al., (2008), Iqbal et al., (2010) and Sarkar et al., (2011).

\section{Changes in $\mathrm{pH}$ and $\mathrm{C}$ : $\mathrm{N}$ ratio}

In the experiment, the $\mathrm{pH}$ of rural and urban waste shifted towards normal at maturity. Final $\mathrm{pH}$ of test consortium treated rural waste was 7.07 while that of urban waste was 6.94. The shift of $\mathrm{pH}$ towards normal is the indication of maturity of compost.

Decrease in $\mathrm{C}$ : $\mathrm{N}$ ratio in all the treatments over control was recorded. The per cent decrease in $\mathrm{C}$ : $\mathrm{N}$ ratio of rural waste over initial was $75.65,73.86$ and 71.95 per cent while of urban waste was $62.66,61.79$ and 60.24 per in treatments with test consortium, commercial consortium and uninoculated control, respectively.

The present results are in conformity with the results of research workers who revealed from their studies that the organic matter decomposes gradually with time, stabilizes with final $\mathrm{pH}$ of compost between 7 to 8 with reduction in C: $\mathrm{N}$ ratio (Ranalli et al., 2001, Gade et al., 2010; Raj and Antil, 2011; Himanen and Hanninen, 2011; Sarker et al., 2013).

\section{Mineral components of compost at maturity}

In in-vivo composting experiment, minor differences in nutrient status was recorded at maturity within different treatments. In both rural and urban waste, the treatment with test consortium numerically recorded higher nutrient content at maturity over control (commercial consortium) and uninoculated control.

Several research workers estimated the nutrient value of compost prepared on inoculation with microbes over the uninoculated control. Patil (1994), Verma et al., (1999) and Sarker et al., (2013) revealed that the compost prepared on inoculation of microbes showed the better nutrient levels compared to uninoculated control. This is probably because of quick microbial activity leading to decrease in volume of the material. The present results are thus in conformity with the work done by earlier research workers.

Application of newly developed microbial consortium consisting of Bacillus sp. (B-28), A. terreus (F-13) and Streptomyces sp. (A-40) on wastes increased the microbial activity, maintain $\mathrm{pH}$ and reduced the period of composting and was superior over the commercial consortium and uninoculated control (Table 3). It is revealed from the results that incorporation of cellulolytic microorganisms enhance the rate of decomposition of organic matter, which will enable to convert the organic matter into valuable compost in short time.

\section{Acknowledgement}

Authors are thankful to the Head, Department of Plant Pathology and Agricultural Microbiology, Mahatma Phule Krishi Vidyapeeth, Rahuri, Dist. Ahmednagar (MS) 
for providing necessary facilities during the investigations.

\section{References}

Bremner, J.M. 1970. Total organic carbon in methods of soil analysis Part-2. Chemical and microbiological properties. Page, A.L (ed). II Edn. Amer. Soc. Agron. Inc. and Soil. Sci. Amer. Inc. Madison, Wisconsin, USA. pp. 475-594.

Fourti, O., Jedidi, N. and Hassen, A. 2008. Behaviour of main microbiological parameters and of enteric microorganisms during the composting of municipal solid wastes and sewage sludge in semi-industrial composting plant. American J. Environ. Sci. 4(2): 103-110.

Gade, R.M., Mane, S.S. and Thakur, K.D. 2010. Decomposition of farm wastes by cellulolytic organism. Journal of Plant Disease Science. 5(1):154-157.

Gaur, A.C. 1982. A manual of rural composting, FAO/UNDP regional project SRAS/75/004, Field document, FAO, Rome. p. 102.

Gazi, A.V., Kyriacou, A., Kotsou, M. and Lasaridi, K.E. 2007. Microbial community dynamics and stability assessment during green waste composting. Global NEST Journal. 9(1): 35-41.

Goyal, S., Dhull, S.K. and Kapoor, K.K. 2005. Chemical and biological changes during composting of different organic wastes and assessment of compost maturity. Bioresource Technology. 96:1584-1591.

Haritha Devi, S., Vijayalakshmi, K., Pavana Jyotsna, K., Shaheen, S.K., Jyothi, K. and Surekha Rani, M. 2009. Comparative assessment in enzyme activities and microbial populations during normal and vermicomposting.
Journal of Environmental Biology. 30(6): 1013-1017.

Hassen, A., Belguith, N., Jedidi, N., Cherif, A., Cherif, M. and Boudabous, A. 2001. Microbial characterization during composting of municipal solid waste. Bioresource Technology. 80: 217-225.

Himanen, M. and Hanninen, K. 2011. Composting of bio-waste, aerobic and anaerobic sludges: Effect of feedstock on the process and quality of compost. Bioresource Technology. 102: 28422852.

Iranzo, M., Sainz-Pardo, I., Boluda, R., Sánchez, J. and Mormeneo, S. 2001. The use of microorganisms in environmental remediation. Ann. Microbiol. 51: 135-143.

Iqbal, M.A., Gupta, S.G. and Arts, M. 2010. Beneficial microbial consortia (BMC): A new approach in treatment of municipal solid waste (MSW) by aerobic composting. Iranica Journal of Energy and Environment. 1(3): 176178.

Jackson, M.L. 1973. Soil chemical analysis. Prentice Hall of India Pvt. Ltd., New Delhi.

Novinsak, A., Surette, C., Allain, C. and Filion, M. 2008. Application of molecular technologies to monitor the microbial content of biosolids and composted biosolids. Water Sci. Technol. 57:471-477

Piper, C.S. 1966. Soil chemical analysis. Hans Publications, Bombay.

Patil, V.S. 1994. Studies on use of wheat straw, PMC and FYM on preparation of vermicompost with Eisenia foetida and its effect on yield and nutrient uptake of wheat. M.Sc. (Agri.) Thesis (Unpub.), MPKV, Rahuri.

Raj, D and Antil, R.S. 2011. Evaluation of maturity and stability parameters of composts prepared from agro-industrial 
wastes. Bioresource Technology. 102(3): 2868-2873.

Ranalli, G., Bottura, G., Taddei, P., Garavani, M., Marchetti, R. and Sorlini, C. 2001. Composting of solid and sludge residues from agricultural and food industries- Bioindicators of monitoring and compost maturity. Journal of Environmental Science and Health, Part A. 36(4): 415-436.

Raut, M.P., Prince William, S.P.M., Bhattacharyya, J.K., Chakrabarti, T. and Devotta, S. 2008. Microbial dynamics and enzyme activities during rapid composting of municipal solid waste- a compost maturity analysis perspective. Bioresource Technology. 99: 65126519.

Sarkar, P., Meghvanshi, M. and Singh, R. 2011. Microbial Consortium: A new approach in effective degradation of organic kitchen wastes. International Journal of Environmental Science and Development. 2(3): 67-71.

Sarker, T., Mannan, M.A., Mondal, P.C., Kabir, A.H., Parvez, S.M. and Alam,
M.F. 2013. Physico-chemical profile and microbial diversity during bioconversion of sugarcane press mud using bacterial suspension. Notulae Scientia Biologicae. 5(3): 346-353

Taiwo, L.B. and Oso, B.A. 2004. Influence of composting techniques on microbial succession, temperature and $\mathrm{pH}$ in a composting municipal solid waste. African J. Biotechnol. 3(4): 239-243.

Verma, L.N., Rawat, A.K. and Rathod, G.S. 1999. Composting process as influenced by the method of aeration. Journal of Indian Society of Soil Science. 47(2):368-371.

Zucconi, F., de Bertoldi, M. 1987. Compost specifications for the production and characterization of compost from municipal solid waste. In: de Bertoldi, M., Ferranti, M.P., L'Hermite, P., Zucconi, F. (Eds.), Compost: Production, Quality and Use. Elsevier, Barking, pp. 30-50.

\section{How to cite this article:}

Game, B.C., C.D. Deokar and More, P.E. 2017. Efficacy of Newly Developed Microbial Consortium for Composting of Rural and Urban Wastes. Int.J.Curr.Microbiol.App.Sci. 6(6): 626-633. doi: https://doi.org/10.20546/ijcmas.2017.606.074 